\title{
Diabetic retinopathy in pregnancy: a 12-year prospective survey
}

\author{
MAGDA HORVAT, HECTOR MACLEAN, LEON GOLDBERG, AND G. W. CROCK \\ From the Prevention of Blindness Unit of the Melbourne University and the Ophthalmic Research \\ Institute of Australia at the Royal Victorian Eye and Ear Hospital, Melbourne, Australia
}

SUMmARY A prospective study extending over 12 years has surveyed 107 latent diabetics and 172 clinical diabetics during pregnancy. Among the clinical diabetics background retinopathy was evident or developed during pregnancy in 40 cases. Eleven cases showed proliferative changes, only 1 such case appearing de novo during gestation. There was a higher incidence of fetal loss in the diabetic than the latent diabetic group, and this loss was highest in those with proliferative retinal disease. Pregnancy was not associated with any increased risk to the mother of progression of retinal changes and visual loss. The only known direct relationship, namely, that between duration of diabetes and ocular complications, is confirmed.

A major fear of both doctor and patient has been that pregnancy in the diabetic may precipitate or aggravate retinopathy and lead to blindness. Because retrospective reports ${ }^{1-3}$ have been conflictting, a prospective survey was begun in 1967 and has involved 279 patients up to 1978 . The course of diabetic eye disease has been studied in relation to pregnancy, and eye ground signs have been evaluated, to see if they might in themselves be sufficient reason for termination of pregnancy. Findings from this study have been analysed and are now presented.

\section{Patients and methods}

Patients attending the antenatal clinics at the Royal Women's Hospital, Melbourne, who had latent or clinical diabetes were seen on a regular basis throughout their pregnancies. They were grouped into latent and clinical diabetics according to the recommendations of the World Health Organisation. ${ }^{4}$ Latent diabetics had either abnormal glucose tolerance tests or frank hyperglycaemia during pregnancy, the latter returning to normal after delivery. The clinical diabetics showed an abnormal response to the glucose tolerance test and symptoms or complications of diabetes.

At each visit, both during pregnancy and after delivery, a full routine ocular examination was made with special note of any retinopathy. Those

Correspondence to Dr Magda Horvat, 32 Gisborne St., East Melbourne, Victoria 3002, Australia. with overt retinopathy at their first visit were reexamined at intervals of 2 to 4 weeks, those with normal ocular fundi 4 to 8 weekly. Mothers were reviewed again in the puerperium and, where possible, 6 monthly thereafter. 107 latent diabetics were followed up through 119 pregnancies and 172 clinical diabetics through 227 pregnancies.

Over the last 3 years of the study all new patients were submitted to routine stereo fluorescein angiography some 6 months after delivery. Earlier patients who were still attending, and as many of the others who could be traced, were similarly examined-in all, a total of 93 patients. When the ophthalmoscopic and angiographic signs differed, angiographic pictures were taken as the basis for classification. It was made a general policy that this investigation was not performed during pregnancy.

The retinal appearances in the clinical diabetics were classified at the patient's first presentation as: normal, background, or proliferative. Included in background retinopathy were microaneurysms, varicose small vessels, retinal haemorrhages, retinal oedema and 'hard' and 'soft' exudates. Stereo angiographic signs included one or more of the following features: capillary bed obliteration, capillary aneurysms, vessel wall varicosities, and staining. When new vessels were seen on the retina, on the disc, or in the vitreous, the retinopathy was labelled proliferative.

The course of the retinopathy was classified under 3 headings: (1) No overall change. There was no observable change in clinical appearances or a 
Table 1 Review attendance pattern-time related

\begin{tabular}{lclcl}
\hline & Latent diabetics & \multicolumn{2}{l}{ Clinical diabetics } & \\
\cline { 2 - 5 } Follow-up & 52 & No retinopathy & Background & Proliferative \\
\hline Not after delivery & 55 & 44 & 8 & 1 \\
$0-4$ years after delivery & 0 & 43 & 20 & 3 \\
$5-9$ years after delivery & 0 & 27 & 9 & 3 \\
$10+$ years after delivery & 107 & 11 & 3 & 0 \\
Total & 2 years & 5 years & 60 & 7 \\
Mean follow-up period & & & 6 years & 4.5 years \\
\hline
\end{tabular}

Table 2 Review attendance pattern-pregnancy-related

\begin{tabular}{lll}
\hline & $\begin{array}{l}\text { Latent } \\
\text { diabetics }\end{array}$ & $\begin{array}{l}\text { Clinical } \\
\text { diabetics }\end{array}$ \\
\hline During 1 pregnancy but not after delivery & 42 & 39 \\
During 1 pregnancy and after delivery & 54 & 80 \\
$\begin{array}{l}\text { Through } 2 \text { pregnancies and after delivery } \\
\text { Through } 3 \text { or more pregnancies and }\end{array}$ & 10 & 42 \\
$\quad$ after delivery & 1 & 11 \\
Total patients & 107 & 172
\end{tabular}

The clinical diabetics have not been subdivided because of the variations in retinal appearances in different pregnancies.

waxing and waning of signs which negated change, as, for example, the appearance and subsequent disappearance of microaneurysms, exudates, or haemorrhages. (2) Progression. The criterion for progression was the appearance of new retinal lesions which persisted. The detection of a single capillary aneurysm in a previously normal fundus merited grading under this heading. (3) Regression. This term was applied where reduction or disappearance of pathological signs were recorded clinically or angiographically.

\section{Results}

The 279 patients comprised 172 clinical diabetics and 107 latent diabetics. The clinical diabetics were subdivided into 47 with retinopathy and 125 without. Sixty-four patients were seen in more than one pregnancy. Analysis of the review pattern is given in Tables 1 and 2 . Of the 93 patients submitted to fluorescein angiography 12, whose retinae were considered normal by ophthalmoscopic examination, were reclassified, on the photographic findings, as having background retinopathy.

\section{Latent Diabetic Group}

No patient showed retinopathy at the initial exami- nation and none developed during pregnancy. Visual acuity at initial examination was $6 / 6$ or better in both eyes of all 107 patients, apart from 4 who had minor refraction anomalies affecting one eye.

After delivery 5 patients became diabetic. Three of these showed no retinopathy after 3 years. The fourth developed background retinopathy within 4 years.

\section{Clinical Diabetic Group}

In this group 215 pregnancies were followed up, all but 3 patients being seen also in the puerperium. A further 12 patients were seen once only and failed to return for any ophthalmic examination after their initial visit.

\section{NORMAL FUNDI}

One hundred and twenty-five patients were found to have normal fundi (Table 3). Seven were seen only once by the ophthalmologist; the other 118 patients were followed up through at least one pregnancy. 123 patients had corrected acuities of $6 / 6$ or better in both eyes at the time of initial examination. The other 2 each had an amblyopic eye. In 1 patient the vision dropped in one eye by 2 lines owing to the development of lens opacities. From among these 125 patients only 1 was observed to develop proliferative retinopathy and then not until some 10 years after the pregnancy. This retinopathy

Table 3 Normal fundi at first examination

\begin{tabular}{lrllll}
\hline $\begin{array}{l}\text { Course during } \\
\text { pregnancy }\end{array}$ & \multicolumn{3}{l}{ Course after delivery } & \\
\cline { 2 - 5 } & Progress & $\begin{array}{l}\text { No } \\
\text { change }\end{array}$ & Regress & $\begin{array}{l}\text { Lost to } \\
\text { follow-up }\end{array}$ \\
\hline Progression & 13 & 2 & 3 & 3 & 5 \\
No change & 105 & 24 & 45 & 0 & 36 \\
No record & 7 & - & - & - & - \\
Total & 125 & & & & \\
\hline
\end{tabular}


regressed after photocoagulation and the patient has retained $6 / 6$ vision in each eye.

\section{BACKGROUND RETINOPATHY}

Forty mothers were found to have background retinopathy at initial presentation (Table 4). They were followed up through 56 pregnancies. Five

Table 4 Diabetics with background retinopathy

\begin{tabular}{lrlrll}
\hline \multirow{2}{*}{$\begin{array}{l}\text { Course during } \\
\text { pregnancy }\end{array}$} & \multicolumn{3}{l}{ Course after delivery } & \\
\cline { 2 - 6 } & & Progress & $\begin{array}{l}\text { No } \\
\text { change }\end{array}$ & Regress & $\begin{array}{l}\text { Lost to } \\
\text { follow-up }\end{array}$ \\
\hline Progression & 11 & 4 & 4 & 1 & 2 \\
No change & 19 & 3 & 11 & 2 & 3 \\
Regressed & 5 & 1 & 2 & 0 & 2 \\
No record & 5 & 0 & 0 & 0 & 0 \\
Total & 40 & 8 & 17 & 3 & 7 \\
\hline
\end{tabular}

failed to return after the first visit and a further seven were not seen after delivery. All but 2 of the cases had corrected vision of $6 / 6$ or better in both eyes. Of these 2,1 had $6 / 18$ as a result of anisometropic amblyopia, the other $6 / 12$ due to lens opacity. The fellow eyes each had acuities of $6 / 5$. Vision remained stable in all patients who did not develop proliferative changes. There were 4 cases with background retinopathy which converted to proliferative. One patient developed new vessels in one eye during her pregnancy. In the other 3 proliferative changes were only noted after their pregnancies. The clinical details are set out in Table 5.

\section{PROLIFERATIVE RETINOPATHY}

Seven patients had proliferative retinopathy at their initial visit and were known to have had it before becoming pregnant for the first time. The features of these cases are summarised in Table 5.

Table 5 Clinical details

\begin{tabular}{|c|c|c|c|c|c|c|c|c|c|c|}
\hline \multirow[b]{2}{*}{ Age } & \multirow[b]{2}{*}{ Parity } & \multicolumn{2}{|c|}{ Initial presentation } & \multicolumn{2}{|c|}{ Change in pregnancy } & \multicolumn{3}{|c|}{ Final result } & \multirow{2}{*}{$\begin{array}{l}\text { Duration } \\
\text { of } \\
\text { diabetes }\end{array}$} & \multirow{2}{*}{$\begin{array}{l}\text { Outcome } \\
\text { of } \\
\text { pregnancy }\end{array}$} \\
\hline & & Fundi & $V A$ & Fundi & $\boldsymbol{V} \boldsymbol{A}$ & Special therapy & Fundi & $V A$ & & \\
\hline 27 & 1 & $\mathbf{R}$ proliferans & $6 / 12,6 / 6$ & No change & $6 / 12,6 / 6$ & Nil & $\begin{array}{l}R \text { vitreous } \\
\text { haemorrhage } 4 \\
\text { months after } \\
\text { pregnancy }\end{array}$ & $6 / 12,6 / 6 \mathrm{pt}$ & 24 years & $\begin{array}{l}\text { Infant death } \\
\text { pneumonia }\end{array}$ \\
\hline 18 & 1 & $\mathbf{R}$ proliferans & $6 / 5,6 / 5$ & No change & $6 / 5,6 / 5$ & Nil & No follow-up & $6 / 5,6 / 5$ & 10 years & Normal \\
\hline 27 & 1 & $\mathbf{R}$ proliferans & $6 / 6,6 / 6$ & $\begin{array}{l}\text { Bilateral } \\
\text { vitreous } \\
\text { haemorrhages }\end{array}$ & $6 / 6,6 / 6$ & $\begin{array}{l}\text { Hypophysectomy } \\
\text { after pregnancy }\end{array}$ & $\begin{array}{l}\text { Haemorrhagic } \\
\text { glaucoma }\end{array}$ & PL, HM & 27 years & Stillbirth \\
\hline 30 & 1 & $\begin{array}{l}\text { Bilateral } \\
\text { vitreous } \\
\text { haemorrhages }\end{array}$ & $6 / 18,6 / 36$ & No change & $3 / 60,6 / 60$ & $\begin{array}{l}\text { Hypophysectomy } \\
\text { after pregnancy }\end{array}$ & $\begin{array}{l}\text { Bilateral dense } \\
\text { vitreous } \\
\text { haemorrhages }\end{array}$ & PL, blind & 17 years & $\begin{array}{l}\text { Termination } \\
\text { for } \\
\text { hypertension }\end{array}$ \\
\hline 33 & 1 & $\mathbf{R}$ proliferans & $6 / 18,6 / 5$ & No change & $6 / 9,6 / 6$ & Lost to & follow-up & & 26 years & $\begin{array}{l}\text { Neonatal } \\
\text { death } \\
\text { (premature) }\end{array}$ \\
\hline 28 & 2 & $\begin{array}{l}\mathbf{R} \text { vitreous } \\
\text { haemorrhages } \\
\mathbf{L} \text { proliferans }\end{array}$ & PL, 6/6 & No change & PL, $6 / 6$ & $\begin{array}{l}\text { Hypophysectomy } \\
\text { during pregnancy }\end{array}$ & $\begin{array}{l}\text { Initial regression } \\
\text { but further new } \\
\text { vessels developed } \\
9 \text { years after } \\
\text { delivery }\end{array}$ & $\begin{array}{l}\text { Blind } 6 / 24 \\
\text { from } \\
\text { cataract } \\
6 / 9 \text { pinhole }\end{array}$ & 22 years & Normal \\
\hline 24 & 1 & L proliferans & $6 / 9,6 / 12$ & No change & $6 / 9,6 / 12$ & Nil & $\begin{array}{l}\text { Regression of } \\
\text { new vessels but } \\
\text { macular changes }\end{array}$ & $6 / 6,6 / 36$ & 22 years & Normal \\
\hline 31 & 4 & Background & $6 / 5,6 / 5$ & Progression & $6 / 5,6 / 5$ & Nil & $\begin{array}{l}\text { Proliferans } 2 \\
\text { years post partum }\end{array}$ & $6 / 6,6 / 60$ & 26 years & $\begin{array}{l}\text { Neonatal } \\
\text { death }\end{array}$ \\
\hline 32 & 1 & Background & $6 / 6,6 / 5$ & $\begin{array}{l}\text { Proliferans L } \\
\text { 3rd trimester }\end{array}$ & $6 / 6,6 / 5$ & Nil & $\begin{array}{l}\text { Progression } \\
\text { despite } \\
\text { photocoagulation }\end{array}$ & $6 / 6,6 / 9$ & 23 years & Normal \\
\hline 28 & 1 & Background & $\begin{array}{l}\text { 6/6pt } \\
6 / 12 \mathrm{pt}\end{array}$ & No change & $\begin{array}{l}\text { 6/6pt, } \\
6 / 12 \mathrm{pt}\end{array}$ & Nil & $\begin{array}{l}\text { Proliferans } 2 \\
\text { month post } \\
\text { partum. Progres- } \\
\text { sion despite } \\
\text { photocoagulation }\end{array}$ & $\begin{array}{l}\text { 6/6pt. } \\
\text { No PL }\end{array}$ & 24 years & $\begin{array}{l}\text { Neonatal } \\
\text { death }\end{array}$ \\
\hline 24 & 1 & Background & $\begin{array}{l}6 / 9 \\
6 / 12 \mathrm{pt}\end{array}$ & $\begin{array}{l}\text { Macular } \\
\text { oedema }\end{array}$ & $6 / 9,6 / 9$ & $\begin{array}{l}\text { Photocoagulation } \\
\text { during pregnancy }\end{array}$ & $\begin{array}{l}\text { Proliferans } 1 \\
\text { month post } \\
\text { partum }\end{array}$ & $6 / 6,6 / 36$ & 22 years & Normal \\
\hline
\end{tabular}

$\mathbf{R}=$ right. $\mathrm{L}=$ left. $\mathrm{VA}=$ visual acuity. $\mathrm{PL}=$ perception of light. $\mathrm{HM}=$ hand movements. 
Table 6 Retinopathy related to age, duration of diabetes, parity, and fetal loss

\begin{tabular}{lllllll}
\hline $\begin{array}{l}\text { Original } \\
\text { description }\end{array}$ & Patients & $\begin{array}{l}\text { Average age } \\
\text { (years) }\end{array}$ & $\begin{array}{l}\text { Average } \\
\text { parity }\end{array}$ & $\begin{array}{l}\text { Overall fetal loss per } \\
\text { number of pregnancies }\end{array}$ & $\begin{array}{l}\text { Average duration } \\
\text { of diabetes (years) }\end{array}$ & $\%$ Fetal loss \\
\hline Latent & 107 & 33.6 & 3.6 & $8 / 119$ & & 6.7 \\
Normal & 118 & 28 & 2.8 & $34 / 164$ & $8 \frac{1}{2}$ & 20.7 \\
Background & 40 & 28.2 & 2.7 & $9 / 56$ & $13 \frac{1}{2}$ & 16.07 \\
Proliferative & 7 & 27.6 & 1.3 & $4 / 7$ & 21 & 57.1 \\
\hline
\end{tabular}

Table 7 Fetal and perinatal losses in clinical diabetics related to eye findings at initial visit and subsequent pregnancy

\begin{tabular}{|c|c|c|c|c|c|c|c|c|c|}
\hline \multirow{3}{*}{$\begin{array}{l}\text { Pregnancy } \\
\text { course }\end{array}$} & \multicolumn{9}{|c|}{ Original description } \\
\hline & \multicolumn{3}{|l|}{ Normal } & \multicolumn{3}{|l|}{ Background } & \multicolumn{3}{|l|}{ Proliferative } \\
\hline & Progression & $\begin{array}{l}\text { No } \\
\text { change }\end{array}$ & $\begin{array}{l}\text { Not } \\
\text { followed up }\end{array}$ & Progression & $\begin{array}{l}\text { No } \\
\text { change }\end{array}$ & Regression & Progression & $\begin{array}{l}\text { No } \\
\text { change }\end{array}$ & Regression \\
\hline Pregnancies & 15 & 144 & 5 & 11 & 40 & 5 & 1 & 5 & 1 \\
\hline Loss & 7 & 23 & 4 & 2 & 6 & 1 & 1 & 3 & 0 \\
\hline
\end{tabular}

MISCELLANEOUS CORRELATIONS

The proportion of patients with known renal disease or hypertension was the same in those who had retinopathy and in those with no retinopathy. Parity at the first visit was highest in the latent diabetics, who were also an older age group, and lowest in the proliferative retinopathy group. A significant correlation was noted between duration of diabetes and stage of retinopathy. The eye signs worsened with increasing duration of diabetes. Further analysis of this correlation in respect of age of onset of diabetes was not significant. The average ages of the patients in the different groups at the time when they were first seen or first developed retinopathy were not significantly different. These facts are tabulated in Table 6.

\section{OUTCOME OF PREGNANCY}

\section{Latent diabetics}

The fetal and perinatal death rate was lowest in this group, with 8 deaths out of 119 pregnancies.

\section{Clinical diabetics}

The clinical details of 47 fetal and perinatal deaths in the 227 pregnancies are shown in Table 7. There were significantly more problems in the clinical diabetics than among latent diabetics $(P<0.002)$, but the differences between the 3 groups of clinical diabetics were not statistically significant because of the small numbers in the proliferative group.

The reasons for termination of pregnancy were recorded as hypertension (2), nephritis (3), and toxaemia (1). In no patient was proliferative change considered the sole indication for terminating the pregnancy. Hypertension was cited as the reason for termination of the pregnancy in 1 patient with proliferative retinopathy. One patient underwent pituitary ablation during pregnancy, yet gave birth to a normal child. ${ }^{5}$ The mortality figures include elective terminations, abortions, stillbirths, and deaths before 1 month of age.

The incidence of retinopathy in our study was $27 \%$ (47 of the 172 clinical diabetics who were examined). Beetham ${ }^{1}$ reported a figure of $41 \%$, Janert et al. ${ }^{2}$ found $34 \%$, and Cassar et al. ${ }^{6}$ recorded an incidence of $18 \%$. The relationship between fetal and perinatal loss is correlated with eye findings in Table 7. Again the unfavourable prognosis associated with proliferative retinopathy is evident.

\section{Discussion}

A simple classification of retinopathy was deliberately adopted for this survey. An attempt to subdivide the retinopathy groups as was done in the Airlie House classification ${ }^{7}$ gave no further useful information because too few patients occupied each category. In the report on their survey of juvenile onset diabetes, Safir and Rogers ${ }^{8}$ made the same point. The 3 principal patterns of change in retinopathy observed in the present series, namely, progression, regression, and waxing and waning with no overall change, coincided with the findings from earlier studies of pregnant diabetics. ${ }^{139}$

The $27 \%$ incidence of retinopathy in this prospective study, when compared with the figures of $41 \%$ reported by Beetham, ${ }^{1}$ of $34 \%$ by Janert et al., ${ }^{2}$ and of $18 \%$ by Cassar et al., ${ }^{6}$ probably reflects 
improved diabetic management over the past 3 decades.

Ocular fundal photography and fluorescein angiography proved valuable in objective assessment of any changes, but the investigation was limited by poor co-operation, particularly from the latent diabetic group. This lack of co-operation may have been due to the fact that many of the patients were recent immigrants to Australia who changed address frequently and who could not be traced subsequently. The policy of not performing angiography during pregnancy provides an additional explanation for this low procedure rate.

At the macula angiography added to clinical observation in 2 ways: by delineating areas of capillary closure adjoining the normal avascular macularfoveal zone, and by demonstrating macular-foveal capillaries to a degree not found previously..$^{10}$ It is important to record that no proliferative retinopathy was seen in the 4 eyes with macular-foveal capillaries, confirming that they are not a variety of intraretinal vascular proliferation.

In 3 of the 10 patients who were followed up through 3 pregnancies, disappearance of retinal microaneurysms was recorded and confirmed angiographically after the first pregnancy. Retinal signs remained stable throughout a subsequent pregnancy, but pathological changes reappeared before or during a still later pregnancy.

In the 1 patient followed up through 4 pregnancies retinopathy was seen during the first and third, but the signs had disappeared within the second and fourth pregnancies. Therefore such events cannot be related to the state of being pregnant but are most probably a reflection of the vicissitudes of diabetic microangiopathy. The lesions of diabetic retinopathy do fluctuate, and not infrequently changes occur in both directions at once, one part of the eye getting better, another part worse. ${ }^{11}$

Progression or development of retinopathy during pregnancy occurred in 1 patient with proliferative retinopathy and in 11 patients with background retinopathy in our series. White ${ }^{39}$ found that in her series 11 developed proliferative retinopathy and 63 background retinopathy in 2147 pregnancies. Cassar et al. ${ }^{6}$ reported 1 patient who developed background retinopathy and 1 proliferative retinopathy during 92 pregnancies.

Our patients were graded on the retinal appearances at their initial visit, so that the data in our Table 7 suggests an unduly high rate of progression of retinopathy when compared with these other series.

Because the risk of progression of retinopathy during pregnancy was previously stated to be high, it had been suggested that diabetic women with any retinopathy should be advised against pregnancy and that proliferative retinopathy was a specific indication for termination. ${ }^{12-14}$ However, the findings from our study confirm the view that the average course of proliferative retinopathy ${ }^{6} 11$ 15-18 is not affected by pregnancy. One of our cases of proliferative retinopathy worsened in pregnancy. Five showed no change. Four background retinopathies converted to proliferative, only 1 during pregnancy. The proliferative retinopathies which progressed did so following pregnancy, 1 as late as 10 years after the delivery.

The use of photocoagulation in patients with proliferative retinopathy advancing during pregnancy has improved their prognosis. ${ }^{6}$ The 6 patients treated during the present study likewise benefited.

The present study found that proliferative retinopathy is associated with more than twice the fetal loss suffered by diabetic mothers with no retinopathy or with background changes. The link between proliferative retinopathy and increased fetal loss is well established. ${ }^{121920}$ Severity of the retinopathy can be correlated with the presence of angiopathy elsewhere, especially in the kidneys. ${ }^{2} 1920$ While the high incidence of fetal morbidity in mothers with proliferative retinopathy may provide supportive advice to terminate a particular pregnancy, the wide ranging suggestion by Okun et al. ${ }^{14}$ that proliferative retinopathy is a specific indication for termination of pregnancy requires modification. The results of the present study and the work of Cassar et al. ${ }^{6}$ establish that pregnancy per se does not lead to inevitable blindness even in the presence of proliferative retinopathy.

Close control of diabetes, especially during pregnancy, appropriate ocular therapy to prevent visual loss, and early admission to hospital for elective induction of labor or planned caesarean section'69151920 now result in a reassuringly high percentage of healthy babies being born to seeing diabetic mothers. These facts, coupled with the general advances in neonatal intensive care, should allow informed, conservative optimism to dominate the 1980s in place of the gloomy prognostications given to earlier generations of diabetic women.

The authors thank Professor P. Taft, Dr F. I. R. Martin, endocrinologists, and Mr R. M. Rome and Mr P. E. Jeffery, obstetricians and gynaecologists, all of whom were jointly responsible for the patients in this study.

\section{References}

${ }^{1}$ Beetham WP. Diabetic retinopathy in pregnancy. Trans Am Ophthalmol Soc 1950; 48: 205-19.

${ }^{2}$ Janert H, Mohrike G, Gunther L. Ophthalmologische Diabetes-studien. I. Linsenbefunde bei 2600 Stationar 
kontrollierten Zuckerkranken. Klin Wochenschr 1956; 34: 742.

${ }^{3}$ White P. Pregnancy and diabetes, medical aspects. Med Clin N Am 1965; 49: 1015.

${ }^{4}$ WHO Tech Rep Ser. 1965; $310: 7$.

${ }^{5}$ Martin FIR, Taft P. Hypophysectomy for diabetic retinopathy during pregnancy. Diabetes $1972 ; 21$ : 972-5.

- Cassar J, Kohner EM, Hamilton AM, Gordon H, Joplin

GF. Diabetic retinopathy and pregnancy. Diabetologia 1978; 15: 105-11.

${ }^{7}$ Goldberg MF, Fine SL, eds. Symposium on the Treatment of Diabetic Retinopathy. Arlington: US Department of Health, Education and Welfare, 1968: 7-37.

${ }^{8}$ Safir A, Rogers SH. Ocular effects of juvenile-onset diabetes. Am J Ophthalmol 1970; 69: 387-92.

${ }^{9}$ White P. Diabetes mellitus in pregnancy. Clin Perinatol $1974 ; 1: 331-47$.

${ }^{10}$ Yeung J, Crock GW, Cairns JD, Heinze J, Troski S, Billson FA. Macular-foveal capillaries in human retina. Aust J Ophthalmol 1973; 1: 17-23.

${ }^{11}$ Davis MD. Definition, classification and course of diabetic retinopathy. In: Lyn JR, Snyder WB, Vaiser A, eds.
Diabetic Retinopathy. New York: Grune and Stratton, 1974: 10.

${ }^{12}$ Landesman R, Douglas RG, Snyder SS. Retinal changes in the toxaemias of pregnancy. Am J Obstet Gynecol 1953; 63: 16.

${ }^{13}$ Marble A, White P, Bradley RF. Joslin's Diabetes Mellitus, 11th ed. Philadelphia: Lea and Feabiger, 1971: 581-98.

${ }^{14}$ Okun E, Johnston GP, Boniuk I. Management of Diabetic Retinopathy. St. Louis: Mosby 1971: 47.

${ }^{15}$ Adler R, Freedman J, Kukar N, Gombos GM. Various parameters of diabetic retinopathy among clinical population. Ann Ophthalmol 1975; 7: 1447-54.

${ }^{16} \mathrm{Kahn}$ HA, Bradley RF. Prevalence of diabetic retinopathy. Br J Ophthalmol 1975; 59: 345-9.

${ }^{17}$ Macourt DC. Diabetes mellitus in pregnancy. Med $J$ Aust 1974; i: 797-802.

${ }^{18} \mathrm{Scott}$ GI. Ocular complications of diabetes mellitus. Br J Ophthalmol 1953; 37: 705-15.

${ }^{19}$ Burt RL, Weaver RG. Proliferative diabetic retinopathy in pregnancy. Obstet Gynecol 1972; 40: 199-201.

${ }^{20}$ Stephens JW, Page OC, Hare RL. Diabetes and pregnancy. Diabetes 1963; 12: 213-9. 